\title{
ALTERNATIVES FOR CHEMICAL MANAGEMENT OF SOURGRASS
}

\author{
CONTROLE QUÍMICO DE CAPIM-AMARGOSO
}

\section{Eraldo Godinho GILO'; Cristiane Gonçalves de MENDONÇA ${ }^{1}$; Tiago Lima do Espírito SANTO' ${ }^{1}$; Paulo Eduardo TEODORO²}

1. Departamento de Fitossanidade da Universidade Estadual de Mato Grosso do Sul - UEMS, Unidade Universitária de Aquidauana UUA, Aquidauana, MS, Brasil; 2. Departamento de Biologia Geral da Universidade Federal de Viçosa - UFV, Viçosa, MG, Brasil.

\begin{abstract}
Intensive use of Glyphosate has been selected multiple resistant sourgrass biotypes in the areas of intensive agriculture in Brazil. Thus, it is important that viable management alternatives are evaluated for this invasion, which currently is regarded as the main problem of Brazilian agriculture. The study aimed to evaluate strategies for chemical management of sourgrass. Three trials divided according to the weed development stages were performed: PostInitial (up to tillering), Post-Delayed (one to four tillers) and Adult-Plant (adult stage characterized by the beginning of the reproductive phase). The sourgrass seeds were collected from biotypes with evidence of Glyphosate tolerance in the municipality of Rio Brilhante - MS. In each trial were evaluated thirteen treatments and one witness, where the treatments were herbicide mixtures applications with subsequent sequential applications at different dates (7,10 and 14 days after the first application) and the herbicides application without mixtures. Sourgrass plants are tolerant to Glyphosate and Clethodim herbicides. Formulated mixtures of Paraquat + Diuron and Haloxifop are the most suitable for controlling sourgrass plants derived from seeds, regardless of the control period. Treatments that have the Haloxyfop herbicide in the first application provided better control when compared to the other treatments with mixtures and sequential applications at all stages of applications.
\end{abstract}

KEYWORDS: Digitaria insularis. Herbicides. Action mechanisms.

\section{INTRODUCTION}

Herbicides whose mechanism of action is inhibition of phenol-piruvilshiquimato phosphate synthase (EPSPs) began to be used in Brazilian agriculture in the late 1970s, but its use began to grow only from the end of the 1980s and early 1990 s with the increased use of no-till system, where prevails the maintenance of the previous crop straw in soybean, maize and wheat cropping systems (KRUSE et al., 2000). Another factor contributing to the growth of glyphosate use in Brazil was the approval of the Biosafety Law in 2005 that allowed the legalized use of genetically modified crops resistant to the herbicide (KOGER; REDDY, 2005).

Glyphosate herbicide is a product of diversified use compared to other herbicides, because it has low toxicity to animals and environment, broad-spectrum control and low cost. These factors have boosted inappropriate weed management in the farmed environment for decades, where it has selected tolerant biotypes of different weed species (ZANUNCIO et al., 2013; TEODORO et al., 2015). Thus, the study of several management alternatives for such species is important (MONQUERO et al., 2001; GALLI; MONTEZUMA, 2005).

Among all species of weeds with tolerance in Brazil, sourgrass (Digitaria insularis (L.) Fedde) is the principal due to its aggressiveness, with a wide geographical distribution and occurring in the most favorable environments for agriculture (MONDO et al., 2010). It is a perennial, which form clumps with rhizomes, produces high amount of easily dispersing seeds, has a rapid early vegetative development and is highly competitive with other plants (LORENZI, 2014).

The first confirmed case about sourgrass biotypes resistant to glyphosate, was in Paraguay in 2006 and in this same year was also confirmed in Brazil (HEAP, 2011).

According to Gomes Junior and Christoffoleti (2008) the new challenge for agriculture is the management of weeds resistant to herbicides. The main limitations of integrated weed management programs is a lack of knowledge, as the correct phenological stage for application, mixtures of herbicides with synergistic effects and dates for sequential applications, which are considered essential for the development of viable management systems under the agronomic, environmental and economic points of view. The use of tank mixtures with herbicides of different action mechanisms, sequential applications and applications in early stages of development has been carried out consistently in several crops such as soybean, maize and cotton aimed at increasing weed control efficiency (CARVALHO et al., 2002). Melo et al. (2012) studied alternatives to control sourgrass 
resistant to glyphosate using post emergent herbicide at different tank mixtures and sequential applications. These authors found that the treatments that have the better results were glyphosate mixed with clethodim complemented by paraquat + diuron 7 days after the first application of glyphosate in combination with clethodim supplemented with ammonium glufosinate 7 days after the first application. Still, glyphosate treatments mixed with haloxyfop, glyphosate + fenoxaprop-p-ethyl + clethodim and glyphosate + tepraloxydim showed excellent performance, with single application.

Still more information is needed to assess the efficacy of herbicides and / or mixtures in control of sourgrass plants at different stages. Thus, this study aimed to evaluate strategies for chemical management of sourgrass.

\section{MATERIAL AND METHODS}

The study was carried out in a greenhouse at the Phytosanity Laboratory of the Universidade Estadual de Mato Grosso do Sul - Unit of Aquidauana, State of Mato Grosso do Sul - MS $\left(20^{\circ} 27^{\prime} \mathrm{S}\right.$ and $\left.55^{\circ} 40^{\prime} \mathrm{W}\right)$.
Three trials divided according to the weed development stages were performed: Post-Initial (until the beginning of tillering), Post-Delayed (one to four tillers) and Adult Plant (adult stage characterized by the beginning of the reproductive phase) (LORENZI, 2014). Sourgrass seeds were collected from biotypes with evidence of tolerance to glyphosate in agriculture area with a history of soybean/maize for more than ten years in the municipality of Rio Brilhante - MS $\left(21^{\circ} 45^{\prime} \mathrm{S}\right.$ e 54 ${ }^{\circ} 52^{\prime} \mathrm{W}$ ), on October 10, 2014.

Trials in a completely randomized design, with six replications were conducted. In each trial were evaluated thirteen treatments and a witness, where the treatments consisted of herbicide mixtures application with posterior sequential applications at different dates (7, 10 and 14 days after the first application) and by herbicides unmixed application (Table 1). The herbicides used were Verdict ${ }^{\circledR}$ (Haloxyfop) at $60 \mathrm{~g}$ a.i./ha, Select ${ }^{\circledR}$ (Clethodim) at $108 \mathrm{~g}$ a.i./ha, Roundup ${ }^{\circledR}$ Original (Glyphosate) at 1,440 g a.i./ha and Gramocil ${ }^{\circledR}$ (Paraquat + Diuron) at $300+150 \mathrm{~g}$ a.i./ha. We used Nimbus ${ }^{\circledR}$ mineral oil at $0.5 \% \mathrm{v} / \mathrm{v}$ in all applications in association with herbicides and mixtures.

Table 1. Description of the treatments.

\begin{tabular}{ccc}
\hline $\mathbf{1}^{\circ}$ Application & $\mathbf{2}^{\circ}$ Application & Sequential (DAFA) \\
\hline Glyphosate + Clethodim & Haloxyfop & 7 \\
Haloxyfop + Glyphosate & Clethodim & 7 \\
Haloxyfop + Clethodim & Glyphosate & 7 \\
Glyphosate + Clethodim & Haloxyfop & 10 \\
Haloxyfop + Glyphosate & Clethodim & 10 \\
Haloxyfop + Clethodim & Glyphosate & 10 \\
Glyphosate + Clethodim & Haloxyfop & 14 \\
Haloxyfop + Glyphosate & Clethodim & 14 \\
Haloxyfop + Clethodim & Glyphosate & 14 \\
Paraquat + Diuron & - & - \\
Haloxyfop & - & - \\
Clethodim & - & - \\
Glyphosate & - & - \\
Sem aplicação & - & - \\
\hline
\end{tabular}

Sowing was performed into 5 liter pots, using subsurface soil, classified as dystrophic Ultisol sandy texture, with the following features: $\mathrm{pH}\left(\mathrm{H}_{2} \mathrm{O}\right)=4,8 ; \mathrm{Al}$ trocável $\left(\mathrm{cmol}_{\mathrm{c}} \mathrm{dm}^{-3}\right)=0.4$; $\mathrm{Ca}+\mathrm{Mg}\left(\mathrm{cmol}_{\mathrm{c}} \mathrm{dm}^{-3}\right)=0.97 ; \mathrm{P}\left(\mathrm{mg} \mathrm{dm}^{-3}\right)=1.8 ; \mathrm{K}$ $\left(\mathrm{cmol}_{\mathrm{c}} \mathrm{dm}^{-3}\right)=0.05 ; \mathrm{H}+\mathrm{Al}\left(\mathrm{cmol}_{\mathrm{c}} \mathrm{dm}^{-3}\right)=5.7$; Organic matter $\left(\mathrm{g} \mathrm{dm}^{-3}\right)=0.8 ; \mathrm{V}(\%)=15.1$. Soil correction was not performed.

Pots were irrigated and identified until reaching the field capacity, and subsequently, the seeds were deposited on the substrate and covered by a thin layer of the same substrate. In the postinitial trial, four plants per pot were maintained, and in post-delayed and adult plant trials two plants per pot were maintained, thus each pot was the experimental unit.

Applications were performed using a costal spray pressurized for $\mathrm{CO}_{2}$, equipped with sixpointed bar, type jet range (XR 11002), spaced 0.50 $\mathrm{m}$, adjusted to spray volume of $150 \mathrm{~L} \mathrm{ha}^{-1}$. 
Application of all treatments was conducted under environmental conditions recommended for spraying, according to the treatments. The first applications were made at 25 days after sowing in Post-Initial, 37 days after sowing in Post-Delayed and 60 days after sowing in the Adult Plant stage. Sequential applications were performed from the counting days depending on these dates.
Assessments of control by herbicides were performed at 7, 14, 21, 28 and 35 days after the first herbicides application (DAFA). For this, we used the visual percentage scale ranging from 0 to $100 \%$, wherein zero corresponds to no symptoms and 100 to the total control of sourgrass using the rating scale (Table 2) proposed by Asociación Latinoamericana de Malezas (ALAM, 1974) .

Table 2. Rating scale proposed by ALAM (1974) for evaluating the percentage of control of sourgrass (Digitaria insularis).

\begin{tabular}{cc}
\hline Percentage & Degree of control \\
\hline $0-40$ & Absent or porr \\
$41-60$ & Regular \\
$61-70$ & Sufficient \\
$71-80$ & Good \\
$81-90$ & Very Good \\
$91-100$ & Excellent \\
\hline
\end{tabular}

ALAM: Asociación Latinoamericana de Malezas.

For being data in percentage, they were transformed into $\sqrt{\mathrm{x}}$. Subsequently, they were subjected to analysis of variance, followed by Scott and Knott test for clustering of averages, both at 5\% probability using the Sisvar 5.3 statistical program (FERREIRA, 2011).

\section{RESULTS AND RESULTS}

Treatments influenced $(\mathrm{p} \leq 0.05)$ in postinitial sourgrass control at 7, 14, 21, 28 and 35 DAFA (Table 3). Machado et al. (2006) and Gemelli et al. (2012) reported that beginning of the sourgrass plants development is the period of highest sensitivity, because the plants have a lower lignin content in the tissue, facilitating the control in the early stages, which was observed in this study when compared to more advanced development stages of the plants.

Table 3. F-values of ANOVA for the control variables of sougrass in Post-Initial at 7, 14, 21, 28 and 35 days after the first herbicides application (DAFA).

\begin{tabular}{ccccccc}
\hline Sources of variation & DF & DAFA7 & DAFA14 & DAFA21 & DAFA28 & DAFA35 \\
\hline Treatmentes & 13 & $65.24^{*}$ & $53.03 *$ & $45.02 *$ & $43,75^{*}$ & $43.17 *$ \\
CV $(\%)$ & --- & 20.77 & 9.74 & 8.96 & 7.94 & 7.86 \\
\hline
\end{tabular}

* significant at $5 \%$ probability by $\mathrm{F}$ test; $\mathrm{CV}$ : coefficient of variation.

At 7 DAFA in Post-Initial, still without the effect of sequential applications, a formulated mixture of Paraquat + Diuron and Haloxyfop, in addition to variations in treatments Haloxyfop + Glyphosate which would be complemented with Clethodim at 7 and 14 DAFA and Haloxyfop + Clethodim which would be complemented with Glyphosate at 7, 10 and 14 DAFA provided sourgrass plants control superior to $80 \%$ (Table 4) and were classified as very good or excellent, according to the rating scale (ALAM, 1974).

At 7 DAFA, Haloxifop herbicide provided control classified as very good. According to
Gemelli et al. (2012), ACCase inhibiting herbicides, effectively control sourgrass plants in the early developing stages, producing the characteristic symptom of necrosis of the growth areas due to blockage of lipid synthesis.

In the assessments at 14, 21, 28 and 35 days after the first application all combinations of treatments, Haloxyfop herbicides and the formulated mixture paraquat + diuron provided $100 \%$ control of sourgrass plants being classified as excellent, according to the rating scale (ALAM, 1974). 
Table 4. Sourgrass control in Post-Initial at 7, 14, 21, 28 and 35 days after the first herbicides application (DAFA).

\begin{tabular}{cccccc}
\hline Treatment & DAFA7 & DAFA14 & DAFA21 & DAFA28 & DAFA35 \\
\hline Glyp + Clet $\rightarrow$ Halo $(7)^{2}$ & $40.0 \mathrm{c}$ & $100.0 \mathrm{a}$ & $100.0 \mathrm{a}$ & $100.0 \mathrm{a}$ & $100.0 \mathrm{a}$ \\
Halo + Glyp $\rightarrow$ Clet $(7)^{2}$ & $82.5 \mathrm{a}$ & $100.0 \mathrm{a}$ & $100.0 \mathrm{a}$ & $100.0 \mathrm{a}$ & $100.0 \mathrm{a}$ \\
Halo + Clet $\rightarrow$ Glyp $(7)^{2}$ & $97.8 \mathrm{a}$ & $100.0 \mathrm{a}$ & $100.0 \mathrm{a}$ & $100.0 \mathrm{a}$ & $100.0 \mathrm{a}$ \\
Glyp + Clet $\rightarrow$ Halo $(10)^{2}$ & $22.2 \mathrm{c}$ & $100.0 \mathrm{a}$ & $100.0 \mathrm{a}$ & $100.0 \mathrm{a}$ & $100.0 \mathrm{a}$ \\
Halo + Glyp $\rightarrow$ Clet $(10)^{2}$ & $73,2 \mathrm{~b}$ & $100.0 \mathrm{a}$ & $100.0 \mathrm{a}$ & $100.0 \mathrm{a}$ & $100.0 \mathrm{a}$ \\
Halo + Clet $\rightarrow$ Glyp $(10)^{2}$ & $97,7 \mathrm{a}$ & $100.0 \mathrm{a}$ & $100.0 \mathrm{a}$ & $100.0 \mathrm{a}$ & $100.0 \mathrm{a}$ \\
Glyp + Clet $\rightarrow$ Halo $(14)^{2}$ & $52,5 \mathrm{~b}$ & $100.0 \mathrm{a}$ & $100.0 \mathrm{a}$ & $100.0 \mathrm{a}$ & $100.0 \mathrm{a}$ \\
Halo + Glyp $\rightarrow$ Clet $(14)^{2}$ & $88,3 \mathrm{a}$ & $100.0 \mathrm{a}$ & $100.0 \mathrm{a}$ & $100.0 \mathrm{a}$ & $100.0 \mathrm{a}$ \\
Halo + Clet $\rightarrow$ Glyp $(14)^{2}$ & $95,2 \mathrm{a}$ & $100.0 \mathrm{a}$ & $100.0 \mathrm{a}$ & $100.0 \mathrm{a}$ & $100.0 \mathrm{a}$ \\
$\left(\right.$ Paqt + Diur) ${ }^{1}$ & $99,5 \mathrm{a}$ & $100.0 \mathrm{a}$ & $100.0 \mathrm{a}$ & $100.0 \mathrm{a}$ & $100.0 \mathrm{a}$ \\
Halo & $89,2 \mathrm{a}$ & $100.0 \mathrm{a}$ & $100.0 \mathrm{a}$ & $100.0 \mathrm{a}$ & $100.0 \mathrm{a}$ \\
Clet & $33,3 \mathrm{c}$ & $62.2 \mathrm{~b}$ & $74.2 \mathrm{~b}$ & $79.2 \mathrm{~b}$ & $80.0 \mathrm{~b}$ \\
Glyp & $5,0 \mathrm{e}$ & $21.0 \mathrm{c}$ & $48.3 \mathrm{c}$ & $56.7 \mathrm{c}$ & $63.3 \mathrm{c}$ \\
Witness & $0,0 \mathrm{e}$ & $0.0 \mathrm{~d}$ & $0.0 \mathrm{~d}$ & $0.0 \mathrm{~d}$ & $0.0 \mathrm{~d}$ \\
\hline
\end{tabular}

Means followed by the same lower case belong to the same group according to the Scott and Knott test at 5\% probability. glyp $=$ glyphosate; clet = clethodim; halo = haloxyfop; paqt = paraquat; diur = diuron; ${ }^{1}$ formulated mixture of products; ${ }^{2}$ days for sequential application.

Clethodim and Glyphosate herbicides, applied in isolation, generated the smaller controls of the trial, achieving good control only after 35 DAFA, which is a confirmation that the plants used in this study were tolerant to these herbicides. Regarding the Clethodim, this result differs those results reported by Adegas et al. (2010), who obtained excellent control of sourgrass plants derived from seeds and up to three tillers, using this herbicide for its control in Londrina, State of Paraná. For glyphosate, the results found in this study corroborates the results obtained by Melo et al. (2012), which found that sourgrass plants used in their work were tolerant to this herbicide after evaluating different herbicides for management of this weed in maize and found only $65 \%$ of control at 28 days after application.

Regarding the Gramocil ${ }^{\circledR}$ herbicide, Oliveira Júnior et al. (2011), reported that the herbicides that have their action mode by inhibition of photosystem I (Paraquat), can drastically to decrease the leaf area of this plant, causing a rapid control in the early stages. This occurs because its application leads to hydrogen peroxide formation in cellular content and subsequently occurs the degradation of cytoplasmic membrane and leakage of cellular contents, causing cell death and accelerating the plant death (MAGALHÃES et al., 2001).
For controlling sourgrass plants at 14,21 , 28 and 35 DAFA, except Clethodim and Glyphosate herbicides, all treatments were efficient (Table 4). These results indicate that formulated mixture of Paraquat + Diuron herbicides and the Haloxyfop isolated were the most suitable, since they require only one application, thus reducing control costs.

Weed control at Post-Initial stage is higher when compared to Post-Delayed and Adult Plant controls, because during the Post-Initial stage, there is better absorption and translocation of herbicides due to lower lignification of plant tissues (OLIVEIRA JÚNIOR et al, 2011). However, the control of this species at the tillering is extremely difficult, as from this stage there is an exponential increase in dry matter and lignification of plant tissues, hindering their control when compared to control in early development stages.

Treatments conducted influenced the control in Post-Delayed $(\mathrm{p} \leq 0.05)$ at $7,14,21,28$ and 35 DAFA (Table 5).

Only the formulated mixture Paraquat + Diuron provided $100 \%$ control of sourgrass plants at 7 DAFA in Post-Delayed stage, differing from the other treatments and is considered excellent according to the rating scale (ALAM, 1974) (Tabela $6)$. 
Table 5. F-values of ANOVA for the variable control of sourgrass plants in Post-Delayed at 7, 14, 21, 28 and 35 days after the first herbicides application (DAFA).

\begin{tabular}{ccccccc}
\hline Sources of variation & DF & DAFA7 & DAFA14 & DAFA21 & DAFA28 & DAFA35 \\
\hline Treatmentes & 13 & $53.99^{*}$ & $44.47^{*}$ & $47.88^{*}$ & $46.78^{*}$ & $46.41^{*}$ \\
CV $(\%)$ & --- & 14.37 & 7.94 & 6.48 & 5.48 & 5.08 \\
\hline
\end{tabular}

* significant at $5 \%$ probability by $\mathrm{F}$ test; $\mathrm{CV}$ : coefficient of variation.

Table 6. Control sourgrass plants in Post-Delayed, at 7, 14, 21, 28 and 35 days after the first herbicides application (DAFA).

\begin{tabular}{cccccc}
\hline Treatment & DAFA7 & DAFA14 & DAFA21 & DAFA28 & DAFA35 \\
\hline Glyp + Clet $\rightarrow$ Halo $(7)^{2}$ & $13.7 \mathrm{c}$ & $67.2 \mathrm{~b}$ & $77.5 \mathrm{~b}$ & $82.3 \mathrm{~b}$ & $91.3 \mathrm{a}$ \\
${\text { Halo }+ \text { Glyp } \rightarrow \text { Clet }(7)^{2}}^{2}$ & $55.8 \mathrm{~b}$ & $90.5 \mathrm{a}$ & $97.7 \mathrm{a}$ & $100.0 \mathrm{a}$ & $100.0 \mathrm{a}$ \\
${\text { Halo }+ \text { Clet } \rightarrow \text { Glyp }(7)^{2}}^{2}$ & $68.3 \mathrm{~b}$ & $78.3 \mathrm{~b}$ & $99.3 \mathrm{a}$ & $100.0 \mathrm{a}$ & $100.0 \mathrm{a}$ \\
Glyp + Clet $\rightarrow$ Halo $(10)^{2}$ & $16.0 \mathrm{c}$ & $40.8 \mathrm{~d}$ & $54.2 \mathrm{c}$ & $68.0 \mathrm{c}$ & $81.0 \mathrm{~b}$ \\
Halo + Glyp $\rightarrow$ Clet $(10)^{2}$ & $53.0 \mathrm{~b}$ & $68.3 \mathrm{~b}$ & $80.8 \mathrm{~b}$ & $94.8 \mathrm{a}$ & $98.3 \mathrm{a}$ \\
Halo + Clet $\rightarrow$ Glyp $(10)^{2}$ & $65.8 \mathrm{~b}$ & $75.0 \mathrm{~b}$ & $96.5 \mathrm{a}$ & $99.2 \mathrm{a}$ & $100.0 \mathrm{a}$ \\
Glyp + Clet $\rightarrow$ Halo $(14)^{2}$ & $11.3 \mathrm{c}$ & $37.5 \mathrm{~d}$ & $49.2 \mathrm{c}$ & $61.7 \mathrm{c}$ & $74.2 \mathrm{~b}$ \\
Halo + Glyp $\rightarrow$ Clet $(14)^{2}$ & $63.5 \mathrm{~b}$ & $73.0 \mathrm{~b}$ & $85.0 \mathrm{~b}$ & $93.2 \mathrm{a}$ & $98.0 \mathrm{a}$ \\
Halo + Clet $\rightarrow$ Glyp $(14)^{2}$ & $73.0 \mathrm{~b}$ & $86.7 \mathrm{a}$ & $92.3 \mathrm{a}$ & $98.5 \mathrm{a}$ & $100.0 \mathrm{a}$ \\
$\left(\right.$ Paqt + Diur) ${ }^{2}$ & $100.0 \mathrm{a}$ & $100.0 \mathrm{a}$ & $100.0 \mathrm{a}$ & $100.0 \mathrm{a}$ & $100.0 \mathrm{a}$ \\
Halo & $65.8 \mathrm{~b}$ & $79.7 \mathrm{~b}$ & $91.2 \mathrm{a}$ & $100.0 \mathrm{a}$ & $100.0 \mathrm{a}$ \\
Clet & $10.8 \mathrm{c}$ & $33.3 \mathrm{~d}$ & $52.5 \mathrm{c}$ & $65.8 \mathrm{c}$ & $80.8 \mathrm{~b}$ \\
Glyp & $8.3 \mathrm{~d}$ & $15.0 \mathrm{e}$ & $17.8 \mathrm{~d}$ & $26.3 \mathrm{~d}$ & $30.8 \mathrm{c}$ \\
Witness & $0.0 \mathrm{e}$ & $0.0 \mathrm{f}$ & $0.0 \mathrm{e}$ & $0.0 \mathrm{e}$ & $0.0 \mathrm{~d}$ \\
\hline
\end{tabular}

Means followed by the same lower case belong to the same group according to the Scott and Knott test at 5\% probability. glyp = glyphosate; clet = clethodim; halo = haloxyfop; paqt $=$ paraquat diur $=$ diuron; ${ }^{1}$ formulated mixture of products; ${ }^{2}$ days for sequential application.

At 7 DAFA, yet without the effect of sequential applications, Glyphosate and Clethodim in isolated form obtained the worst results, which can be classified as absent or poor according to the rating scale (ALAM, 1974).

At 14 DAFA, variations of the treatements Haloxyfop + Glyphosate complemented by an application of Clethodim to 7 days after the first application and Haloxyfop + Clethodim that would be complemented with an application of glyphosate at 14 days after the first application also provided excellent control of sourgrass (ALAM, 1974), além do herbicida Paraquat + Diuron.

At 21 DAFA, the formulated mixture Paraquat + Diuron, Haloxyfop herbicide, the combinations Haloxyfop + Clethodim complemented by an application of glyphosate at 7 , 10 and 14 days, and the combination Haloxyfop + Glyphosate complemented with an application of Clethodim at 7 days obtained excellent control according to the rating scale (ALAM, 1974).
At 28 DAFA, Clethodim and Glyphosate and the associations Glyphosate + Clethodim complemented with one application of Haloxyfop at 7, 10 and 14 were the worst controls, not reaching excellent control (ALAM, 1974). At 35 DAFA, we verified that the Glyphosate herbicide obtained just $30.8 \%$ of control, being considered as absent or poor, while the other treatments provided controls close to $100 \%$. This difficulty in sourgrass control is related tolerance that they have to this herbicide due to mutations in plants, which cause changes in uptake, translocation and even sites of action (CORREIA et al., 2010).

It is worth mentioning that the Haloxyfop herbicide provided $100 \%$ control at 28 and 35 DAFA (Table 6). This reveals that the action of this herbicide in sourgrass plants at Post-Delayed is late, but effective.

Similar results to this study was obtained by Adegas et al. (2010), who verified that the applying Gramoxone ${ }^{\circledR}$ (Paraquat) and Verdict ${ }^{\circledR}$ (Haloxyfop) 
in sourgrass plants with up to two tillers is possible to achieve control levels greater than $90 \%$.

However, when dealing with contact herbicides, Gemelli et al. (2012) reported that its application should be avoided during the reproductive stage of weeds, as they are not able to act in lignified tissues and storage organs. Thus, even if the plants yet have few tillers, it is possible that they already have begun training its rhizomes and, therefore, they already have the ability to issue new tillers using the stored reserves in the rhizomes.

Treatments influenced the sourgrass control at Adult Plant $(\mathrm{p} \leq 0.05)$ at $7,14,21,28$ and 35 DAFA (Table 7).

Table 7. F-values of ANOVA for the variable control of sourgrass plants in Adult Plant stage at 7, 14, 21, 28 and 35 days after the first herbicides application (DAFA).

\begin{tabular}{ccccccc}
\hline Sources of variation & GL & DAFA7 & DAFA14 & DAFA21 & DAFA28 & DAFA35 \\
\hline Treatmentes & 13 & $29.78^{*}$ & $33.04^{*}$ & $35.95^{*}$ & $40.10^{*}$ & $41.90^{*}$ \\
CV $(\%)$ & & 14.70 & 10.06 & 8.33 & 7.40 & 6.56 \\
\hline * & &
\end{tabular}

* significant at $5 \%$ probability by $\mathrm{F}$ test; $\mathrm{CV}$ : coefficient of variation.

According to Gemelli et al. (2012), control of adult weeds is only possible with the use of herbicides with different action mechanisms and use strategies (translocation until the rhizomes and destruction of leaf area). Therefore, in many cases, the management of this weed will not be successfully performed only with a single herbicide application, as it is a perennial species, able to establish itself throughout the year, and management actions should be carried out the entire year in an integrated manner.

Table 8. Control of sourgrass in Adult Plant stage 7, 14, 21, 28 and 35 days after the first herbicide application (DAFA).

\begin{tabular}{cccccc}
\hline Treatment & DAFA7 & DAFA14 & DAFA21 & DAFA28 & DAFA35 \\
\hline Glyp + Clet $\rightarrow$ Halo $(7)^{2}$ & $6.7 \mathrm{~d}$ & $26.7 \mathrm{~d}$ & $37.5 \mathrm{e}$ & $48.3 \mathrm{~d}$ & $60.0 \mathrm{c}$ \\
${\text { Halo }+ \text { Glyp } \rightarrow \text { Clet }(7)^{2}}^{2}$ & $21.7 \mathrm{c}$ & $36.8 \mathrm{c}$ & $54.2 \mathrm{~d}$ & $68.3 \mathrm{c}$ & $80.8 \mathrm{~b}$ \\
Halo + Clet $\rightarrow$ Glyp $(7)^{2}$ & $36.7 \mathrm{~b}$ & $54.2 \mathrm{~b}$ & $78.3 \mathrm{~b}$ & $95.2 \mathrm{a}$ & $99.7 \mathrm{a}$ \\
Glyp + Clet $\rightarrow$ Halo $(10)^{2}$ & $9.2 \mathrm{~d}$ & $16.7 \mathrm{e}$ & $32.5 \mathrm{e}$ & $46.7 \mathrm{~d}$ & $60.0 \mathrm{c}$ \\
Halo + Glyp $\rightarrow$ Clet $(10)^{2}$ & $20.0 \mathrm{c}$ & $37.5 \mathrm{c}$ & $50.8 \mathrm{~d}$ & $77.2 \mathrm{~b}$ & $80.0 \mathrm{~b}$ \\
Halo + Clet $\rightarrow$ Glyp $(10)^{2}$ & $28.3 \mathrm{c}$ & $50.0 \mathrm{~b}$ & $68.3 \mathrm{c}$ & $83.0 \mathrm{~b}$ & $94.3 \mathrm{a}$ \\
Glyp + Clet $\rightarrow$ Halo $(14)^{2}$ & $7.5 \mathrm{~d}$ & $18.3 \mathrm{e}$ & $48.3 \mathrm{~d}$ & $65.0 \mathrm{c}$ & $77.5 \mathrm{~b}$ \\
Halo + Glyp $\rightarrow$ Clet $(14)^{2}$ & $27.2 \mathrm{c}$ & $45.0 \mathrm{c}$ & $63.3 \mathrm{c}$ & $77.5 \mathrm{~b}$ & $88.8 \mathrm{a}$ \\
Halo + Clet $\rightarrow$ Glyp $(14)^{2}$ & $20.0 \mathrm{c}$ & $38.3 \mathrm{c}$ & $59.2 \mathrm{c}$ & $76.7 \mathrm{~b}$ & $91.7 \mathrm{a}$ \\
$\left(\right.$ Paqt + Diur) ${ }^{2}$ & $85.8 \mathrm{a}$ & $96.0 \mathrm{a}$ & $99.7 \mathrm{a}$ & $100.0 \mathrm{a}$ & $100.0 \mathrm{a}$ \\
Halo & $39.2 \mathrm{~b}$ & $60.8 \mathrm{~b}$ & $77.5 \mathrm{~b}$ & $91.3 \mathrm{a}$ & $95.5 \mathrm{a}$ \\
Clet & $10.0 \mathrm{~d}$ & $21.7 \mathrm{~d}$ & $35.0 \mathrm{e}$ & $50.0 \mathrm{~d}$ & $69.2 \mathrm{~b}$ \\
Glyp & $6.3 \mathrm{~d}$ & $11.3 \mathrm{f}$ & $19.2 \mathrm{f}$ & $25.5 \mathrm{e}$ & $30.8 \mathrm{~d}$ \\
Testemunha & $0.0 \mathrm{e}$ & $0.0 \mathrm{~g}$ & $0.0 \mathrm{~g}$ & $0.0 \mathrm{f}$ & $0.0 \mathrm{e}$ \\
\hline
\end{tabular}

Means followed by the same lower case belong to the same group according to the Scott and Knott test at 5\% probability. glyp $=$ glyphosate; clet $=$ clethodim; halo $=$ haloxyfop; paqt $=$ paraquat diur $=$ diuron $;{ }^{1}$ formulated mixture of products; ${ }^{2}$ days for sequential application.

At 7, 14 and 21 DAFA, just the Gramocil® (Paraquat + Diuron) herbicide presented satisfactory control $(85.8 \%)$ and is considered very good in the evaluation at 7 days and excellent at 14 and 21 days (ALAM, 1974) (Tabela 8).

At 28 DAFA, in addition to the formulated mixture Paraquat + Diuron, the herbicide Haloxyfop and the association Haloxyfop + Clethodim complemented by one application of Glyphosate at 7 days after the first application also showed excellent control.

At 35 DAFA, besides Haloxyfop and Paraquat + Diuron, the combinations Haloxyfop + Clethodim complemented by one application of Glyphosate at 7, 10 and 14 days and Haloxyfop + Glyphosate complemented by one application of 
Clethodim at 14 days provided satisfactory controls ranging from very good to excellent. At all development stages of sourgrass plants, treatments with tank mixtures and sequential applications that had the herbicide Haloxyfop in the first application provided better control when compared to the other treatments with mixtures and sequential applications.

For all evaluation dates, Glyphosate herbicide showed unsatisfactory control, getting just $30.8 \%$ of control at 35 DAFA, being considered as absent or poor (ALAM, 1974). Sourgrass tolerance to Glyphosate and Clethodim were proven at every application stages, as it has not been observed the death of any evaluated plant even in the early development stage.

Like the other application stages of the different treatments, for Adult Plant the formulated mixture Paraquat + Diuron herbicides provided the greatest control percentages (Table 8), regardless of the evaluation period. Procópio et al. (2006) observed control levels at just $50 \%$ in adult plants of sourgrass with the use of this herbicide and reported a high incidence of regrowth.
The formulated mixture Paraquat + Diuron provides excellent control of sourgrass in Adult Plant stage, but in this study controlled plants were derived from seeds, i.e., weeds without prolonged cycle. According to Oliveira Júnior et al. (2011), the control provided by the action of Paraquat occurs only in weeds without prolonged cycle, since it only has contact action on non-lignified tissues (desiccation).

\section{CONCLUSIONS}

Sourgrass plants are tolerant to Glyphosate and Clethodim herbicides, due to low control levels provided in all weeds development stages.

Formulated mixtures of Paraquat + Diuron and Haloxifop are the most suitable for controlling sourgrass plants derived from seeds, regardless of the control period.

Treatments that have the Haloxyfop herbicide in the first application provided better control when compared to the other treatments with mixtures and sequential applications at all stages of applications.

RESUMO: O uso intensivo do herbicida glyphosate tem selecionado vários biótipos resistentes de capimamargoso nas áreas de agricultura intensiva no Brasil. Dessa forma, é importante que sejam estudadas alternativas viáveis de manejo para esta invasora, que hoje é considerada como um dos principais problemas da agricultura brasileira. O trabalho teve como objetivo a avaliação de estratégias para o manejo químico de capim-amargoso. Foram realizados três experimentos divididos em função dos estágios de desenvolvimento da planta daninha: Pós-inicial (até o perfilhamento), Pós-tardio (um a quatro perfilhos) e Planta Adulta de capim-amargoso (estágio adulto, caracterizado pelo inicio da fase reprodutiva). As sementes de Capim-amargoso foram coletadas de biótipos com indícios de tolerância ao herbicida Glyphosate no município de Rio Brilhante - MS. Em cada experimento foram avaliados treze tratamentos e uma testemunha, onde os tratamentos foram constituídos por aplicações de misturas de herbicidas com posteriores aplicações sequenciais com diferentes datas de aplicações da sequencial (7, 10 e 14 dias após a primeira aplicação) e pela aplicação de herbicidas sem misturas. As plantas de Capim-amargoso apresentam tolerância aos herbicidas Glyphosate e Clethodim. A mistura formulada dos herbicidas Paraquat + Diuron e o herbicida Haloxifop foram os melhores para o controle de plantas de capim-amargoso provenientes de sementes, independente da época de controle. Os tratamentos que possuem o herbicida Haloxifop na primeira aplicação proporcionaram melhores controles quando comparados aos demais tratamentos com misturas e aplicações sequenciais em todos os estágios de aplicações.

PALAVRAS-CHAVE: Digitaria insularis. Herbicidas. Mecanismos de ação. Resistência a herbicidas.

\section{REFERENCES}

ADEGAS, F. S.; GAZZIERO, D. L. P.; VOLL, E.; OSIPE, R. Alternativas de controle químico de Digitaria insularis resistente ao herbicida glyphosate. In: CONGRESSO BRASILEIRO DA CIÊNCIA DAS PLANTAS DANINHAS, 27,. Ribeirão Preto, SP. 2010. Resumos expandidos.... Ribeirão Preto: SBCPD, n. 161, 2010.

ASOCIACIÓN LATINO AMERICANA DE MALEZAS - ALAM. Recomendaciones sobre unificación de los sistemas de evaluación en ensayos de control de malezas. ALAM, Caracas, v. 1, n. 1, p. 35-38, 1974. 
CARVALHO, F. T.; ALVARENGA, S. L. A.; PERUCHI, M.; PALAZZO, R. R. B. Eficácia do carfentrazoneethyl aplicado no manejo das plantas daninhas para o plantio direto do algodão. Revista Brasileira de Herbicidas, Londrina, v. 3, n. 2-3, p. 104-108, 2002. http://dx.doi.org/10.7824/rbh.v3i2-3.379

CORREIA, N. M.; LEITE, G. J.; GARCIA, L. D. Resposta de diferentes populações de Digitaria insularis ao herbicida glyphosate. Planta Daninha, Viçosa, v. 28, n. 4, p. 769-776, 2010.

FERREIRA, D. F. Sisvar: a computer statistical analysis system. Ciência e Agrotecnologia (UFLA), Lavras, v. 35, n. 6, p. 1039-1042, 2011.

GALLI, A. J. B.; MONTEZUMA, M. C. Alguns aspectos da utilização do herbicida glifosato na agricultura. São Paulo: Monsanto do Brasil; 2005. 60 p.

GEMELLI, A.; OLIVEIRA JUNIOR, R. S.; CONSTANTIN, J.; BRAZ, G. B.P.; JUMES, T. M. C.;

OLIVEIRA NETO, A. M.; DAN, H. A.; BIFFE, D. F. Aspectos da biologia de Digitaria insularis resistente ao glyphosate e implicações para o seu controle. Revista Brasileira de Herbicidas, Londrina, v. 11, n. 2, p. 231240, 2012. http://dx.doi.org/10.7824/rbh.v11i2.186

GOMES JUNIOR, F. G.; CHRISTOFFOLETI, P. J. Biologia e manejo de plantas daninhas em área de plantio direto. Planta daninha, Viçosa, v. 26, n. 4, p. 789-798, 2008.

HEAP, I. The international survey of herbicide resistant weeds. 2011. Disponível em: www.weedscience.com. Acesso em: 04 de outubro de 2015.

KOGER, C. H.; REDDY, K.N. Role of absorption and translocation in the mechanism of glyphosate resistance in horseweed (Conyza canadensis). Weed Science, Washington, v. 53, p. 84-89, 2005.

http://dx.doi.org/10.1614/WS-04-102R

KRUSE, N. D.; TREZZI, M. M.; VIDAL, R. A. Herbicidas inibidores da EPSPs: revisão de literatura. Revista Brasileira de Herbicidas, Londrina, v. 2, n. 1, p. 139-146, 2000. http://dx.doi.org/10.7824/rbh.v1i2.328

LORENZI, H. Manual de identificação e controle de plantas daninhas: Plantio direto e convencional. 7. ed. Nova Odessa, 2014. 383p.

MACHADO, A. F. L. FERREIRA, L. R.; FERREIRA, F. A.; FIALHO, C. M. T.; TUFFI SANTOS, L. D.; MACHADO, M. S. Análise de crescimento de Digitaria insularis (L.) Fedde. Planta Daninha, Viçosa, v. 24, n. 4, p. 641-647, 2006.

MAGALHÃES, P. C. Efeito de doses reduzidas de glyphosate paraquat simulando deriva na cultura do milho. Planta Daninha, Viçosa, v. 19, n. 2, p. 247-253, 2001.

MELO, M. S. C.; ROSA, L. E.; BRUNHARO, C. A. C. G.; NICOLAI, M.; CHRISTOFFOLETI, P. J. Alternativas para o controle químico de capim-amargoso (Digitaria insularis) resistente ao glyphosate. Revista Brasileira de Herbicidas, Londrina, v. 11, n. 2, p. 195-203, 2012. http://dx.doi.org/10.7824/rbh.v11i2.145

MONDO, V. H. V.; CARVALHO, S. J. P.; DIAS, A. C. R.; MARCUS FILHO, J. Efeitos da luz e temperatura na germinação de sementes de quatro espécies de plantas daninhas do gênero Digitaria. Revista Brasileira Sementes, Londrina, v. 32, n.1, p.131-137, 2010. http://dx.doi.org/10.1590/S0101-31222010000100015

MONQUERO, P. A.; CHRISTOFFOLETI, P. J.; SANTOS, C. T. D. Glyphosate em mistura com herbicidas alternativos para o manejo de plantas daninhas. Planta Daninha, Viçosa, v. 19, n. 3, p. 375-380, 2001. http://dx.doi.org/10.1590/s0100-83582001000300010

OLIVEIRA JÚNIOR, R. S.; CONSTANTIN, J.; INOUE, M. H. Biologia e manejo de plantas daninhas. Curitiba: Omnipax Editora, 2011. 348p. 
PROCÓPIO, S. O.; PIRES, F. R.; MENEZES, C. C. E.; BARROSO, A .L. L.; MORAES, R. V.; SILVA, M. V. V.; QUEIROZ, R. G.; CARMO, M. L. Efeitos de dessecantes no controle de plantas daninhas na cultura da soja. Planta Daninha, Viçosa, v. 24, n. 1, p. 193-197, 2006. http://dx.doi.org/10.1590/s010083582006000100024

RODRIGUES, B. N.;: ALMEIDA, F. S. Guia de herbicidas. 5. ed. Londrina, 2005. 592p.

TEODORO, P. E.; RIBEIRO, L. P.; CORREA, C. C. G.; LUZ JUNIOR, R. A. A.; SOUZA, M. C.; SIMOES, M. S.; TORRES, F. E. Phytosociology of weeds in millet under different soil managements in savanna sulmato-grossense. Bioscience Journal, Uberlândia, v. 31, p. 988-996, 2015. http://dx.doi.org/10.14393/BJv31n4a2015-26101

ZANUNCIO, A.; TEODORO, P. E.; RIBEIRO, L. P.; CORREA, C. C. G.; OLIVEIRA, M. A.; TORRES, F. E. Alelopatia de adubos verdes sobre Cyperus rotundus. Revista de Ciências Agrárias, Lisboa, v. 36, p. 441-446, 2013. 